\title{
Nishmat Kol Hai: A Literary and Spiritual Commentary
}

\author{
Jeffrey Hoffman
}

It is a delight to dedicate this essay to Rabbi Joel Roth. Rabbi Roth inspired me early in my rabbinic training as my Talmud teacher (including a wonderfulgroup study of a chapter of Sanhedrin with now-rabbis Phil Scheim and Jay Rosenbaum) and has sustained me ever since as my Poseq. Rabbi Roth's passion for studying and teaching the classic texts of our tradition, and his dedication to living the life of a scholarly religious leader provided a wonderful model for his students. The following commentary, part of a larger work I am preparing on the Siddur, represents one small shibbolet of the lekket that has come to fruition from the seeds planted by this master-teacher.

\section{Literary Commentary}

One of the most prominent differences between the weekday and Shabbat Shaharit service is found at the conclusion of Pesukei DeZimra. On weekdays, Yishtabah is the blessing that forms the concluding bookend paralleling the opening bookend of Barukh She'Amar. On Shabbat and festivals, Yishtabah itself constitutes the concluding paragraph of a much longer poem called (after its first three words) Nishmat Kol Hai, "The Breath of All." I will briefly survey some of the history of this text and then analyze its interesting literary structure.

When the Mishnah discusses the Passover Seder, ${ }^{1}$ it says that the chanting of Hallel (Psalms 114-118) is followed by Birkat HaShir, "The Blessing of Song." Two sages of the Talmud were divided regarding the identity of this blessing. ${ }^{2}$ One held that this blessing is Yehallelukha, "May They Bless You." The blessing concluding Hallel in post-talmudic prayer collections begins with the word Yehallelukha. The other held that it was Nishmat Kol Hai. As is typical of the

1 m. Pesah. 10:7.

2 B. Pesah. 118a.

(C) JEFFREY HOFFMAN, 2021 | DOI:10.1163/9789004420465_006

This is an open access chapter distributed under the terms of the CC BY-NC-ND 4.9license. Hoffman - 9789004420465 
Talmud, the full versions of these prayers are not recorded, assuming perhaps, that its readers were quite familiar with the wording. We cannot, therefore, be confident that extant versions completely match the putative Talmudic wording. ${ }^{3}$ Since the Talmud does not come to a conclusion as to which one of these is Birkat HaShir, many Haggadot include both. Nevertheless, only Nishmat Kol Hai concludes Pesukei DeZimra on Shabbat and festivals.

A series of verses found in Nishmat Kol Hai is also cited as one talmudic sage's version of a blessing to be recited upon the appearance of rain after a drought. ${ }^{4}$ The series of verses begins "Were our mouths as full as song as the sea and our mouths (full of) song as the roar of the sea ..., we still would not adequately thank You." Perhaps the two allusions to water comprise the connection to the rain that the blessing celebrates. It may be that one blessing borrowed the phrase from the other or it could have been a stock expression of praise. ${ }^{5}$

A remarkable comment found in the 12th century Mahzor Vitry and other contemporaneous sources denies that the author of Nishmat Kol Hai was

3 An interesting connection between later versions of Yehallukha and Nishmat Kol Hai is that they both share the exact wording of one sentence: yodu vivarkhu vishabhu vifa'aru viromemu veya'aritzu veyakdishu veyamlikhu et shimkha malkeinu, "let them thank and bless and praise and exalt and glorify and exalt and sanctify and accept the sovereignty of Your name, our king." Whether one blessing borrowed this wording from the other is not clear. An amazing cantorial rendition of this line, emphasizing, in staccato fashion, the repetition of eight synonymic verbs in a row, was recorded by Yossele Rosenblatt. This famous version is found, among other places, on The Complete Cantorial Collection (Tel-Aviv: Israel Music, 2006).

$4 \mathrm{~m}$. Ber. 9:2; b. Ber. 59b. The citation in the Talmud is Ilu finu malei shirah kayam, etc., ein anu maspikim lehodot lekha Adonai Eloheinu ad 'tishtahaveh,' "Were our mouth as full of song as the sea, etc., we still would not adequately thank You, Adonai, our God, until 'bow.' This parallels over one hundred words in the modern version of Nishmat, but again, it is not clear what the version was in the Talmudic period.

5 When the Talmud discusses at what point, early in the rainy season, one should recite the blessing over rain (i.e., when the first droplets appear or when the rain is steady, etc.), it replies, "From the time the groom goes out to meet the bride," that is, when drops of rain ricochet from puddles back up toward the rain that is falling. It may be that because this marriage imagery is associated in rabbinic literature with Shabbat, that Nishmat Kol Hai was transferred from the Haggadah to the conclusion of Pesukei DeZimra on Shabbat (and from there, to the pilgrimage festivals). While that is possible, marriage imagery is found in many settings in rabbinic literature, and even granting the major connection between marriage imagery and Shabbat, there are dozens of other images in this long prayer, and the groom/bride to which he refers isn't even mentioned in the prayer itself; it is mentioned in the context of another setting (the onset of rain) for one passage from this prayer. More evidence than this is needed before one can account for the transference of Nishmat from Pesah to Shabbat. Below, I suggest a connection between the very beginning of Nishmat and the wording of the service on Shabbat morning just before and just after its location in the service. 
Simon (also called Peter), the apostle of Jesus! If this suggestion had to be denied, it is evident that at least some people had asserted that he was, indeed, the author:

There are those who say that that scoundrel Simon Peter the ass ${ }^{6}$ is the author of this and other prayers when he was on the rock. This is an error (worthy of) hell. God forbid that such a thing should occur among Israel. Anyone who makes this claim will have to bring a substantial, large sin offering when the Temple is rebuilt. ${ }^{7}$

This tradition can be traced back to a short medieval Jewish text sometimes called Aggadeta deShimon Kefa, "The Aggadah of Simon Kefa" (Kefa is Aramaic for "Peter," i.e., "rock," a reference to Matt 16:13-19). ${ }^{8}$ The identification of the author of Nishmat Kol Hai with the apostle Peter must be regarded as in the realm of myth since there is no historical evidence to support it. However, the attribution of this prayer to Simon/Peter the Apostle is part of a larger, extraordinary, legend found in these texts. According to these teachings, Simon/Peter, an elder among the Jews at the time of Jesus, volunteered to "go undercover," as it were, and infiltrate the newly emerging Christian religion in order to protect Jews and Judaism. Christian tradition teaches that Simon/Peter was made

6 A play on Exod 34:20, u'feter hamor, "the firstling of an ass." Reading the Hebrew word feter, "firstling" as a transliteration, the phrase may be read as "Peter, the ass." Especially since according to the rules of Hebrew grammar there are occasions when a peh at the beginning of a word loses a dagesh, it may be all the more appropriate that $u^{\prime}$ feter could be construed as a reference to Peter.

7 Aryeh Goldschmidt, ed., Mahzor Vitry by R. Simhah bar Shmuel (Jerusalem: Mekhon Otsar Ha-Poskim, 2004), 2: 412. And see the notes there regarding the other prayers attributed to Simon the Apostle. The editor, in n. 20, observes that the previous critical edition of Mahzor Vitry (the 186o edition edited by Simeon Hurwitz and Heinrich Brody) emended this passage to read ta'ut shel Roma ("error of Rome") by changing the dallet of Duma ("Hell") to a resh ("Roma"). The editor criticizes this emendation since there is, he claims, support for understanding the image of Duma itself as a symbol of Rome, and then marshals as evidence y. 'Abod. Zar. 3:6, 42d-43a and Gen. Rab. 39. However, I find no support for this claim in those two passages, though there is support in another place in the Palestinian Talmud, namely, y. Ta'an. 1:1, 64a in which it is said that in R. Meir's copy of The Book of Isaiah, the prophecy of doom pronounced against the locale called "Duma" is identified as Rome.

8 Three versions of this tradition were published by Adolph Jellinek: Bet ha-Midrasch: Sammlung kleiner Midraschim und vermischter Abhandlungen aus der alteren judischen Literatur (Vienna, 1873 and 1878 = Jerusalem, 1938), 5:6o-62; 6:9-11, 155-156. English translations and analysis may be found in Wout Van Bekkum, "The Rock on Which the Church Is Founded: Simon Peter in Jewish Folktale," in Saints and Role Models in Judaism and Christianity, ed. Marcel Poorthuis, Joshua Schwartz (Leiden: Brill, 2004), 289-310. See also idem, "The Poetical Qualities of the Apostle Peter in Jewish Folktale," Zutot 4 (2004): 16-25. 
the first bishop of Rome (and so, the first Pope). These medieval Jewish traditions claim that this appointment was all part of the Jewish Simon/Peter's plan. In Rome, he had a tower built for himself wherein he could live alone and conduct a secret Jewish life, while at the same time, he could issue laws that separated Christianity from Jewish practice, thus protecting Judaism. He also issued instructions not to harm Jewish communities and individuals. These legends go on to say that during his years in Rome, he composed numerous liturgical poems. ${ }^{9}$

It may be that Nishmat Kol Hai was identified as one of the hymns composed by Simon/Peter because this prayer contains wording which clearly asserted that there is no other god or savior other than the one God:

And other than You, we have no king who redeems, saves (moshi'a, same root as Yeshu, Jesus), rescues, sustains and deals mercifully at every instance of difficulty and distress. We have no king but You ...

While this is reasonable, it must also be said that the passage cited from Nishmat Kol Hai constitutes a very small segment of this long prayer and both its wording and the supposedly supportive commentary of Rabbi Eleazar of Worms (who does not mention Simon/Peter at all) constitute stock monotheistic declarations found throughout the liturgy.

Most interesting is the proposal for explaining the reason that the Sheliah Tzibbur who leads Shaharit in Ashkenazic custom begins chanting from the words shokhen ad within Nishmat Kol Hai instead of from Barekhu (which actually is the beginning of Shaharit). The suggestion is that the letter shin (the first letter of Shimon, "Simon" in Hebrew) with which shokhen ad begins is, according to a folk tradition, meant to invoke the name Shimon, which itself is encoded and spelled backwards over various intervals in Nishmat Kol Hai. ${ }^{10}$ This theory, while suggestive, lacks substantiation and so must be left in the realm of the speculative.

In any case, the wording of this lengthy blessing is nearly identical in all rites, which may attest to its ancient pedigree. ${ }^{11}$

9 Shmuel David Luzzatto (180o-1865), in the introduction to the Italian Prayer Book mentions him as the author of a hymn for Yom Kippur and cites a responsum by Rabbenu Tam (1100-1171) establishing Simon/Peter as the author of another piyyut for Yom Kippur. See the citations in van Wout, "The Rock on Which the Church Is Founded," 307, and nn. 69-71.

10 The folk tradition is mentioned by J.D. Eisenstein, A Digest of Jewish Laws and Customs [in Hebrew] (New York: Hebrew Publishing Company, 1938), 279. I am happy to express thanks to my colleague and friend, Prof. David Golinkin, for alerting me to this citation.

11 Ismar Elbogen, Jewish Liturgy: A Comprehensive History (Philadelphia: Jewish Publication Society; New York: Jewish Theological Seminary, 1993), 96. 
The location of this prayer at the conclusion of Pesukei DeZimra may be related to the fact that its first words parallel those of the last verse of Psalm 15o. It is likely that the original core of Pesukei DeZimra comprised the last six psalms of the Book of Psalms, Psalms $145^{-150.12}$ Thus, this prayer begins by invoking the last words of the last psalm:

Psalm 150: Kol ha-neshamah ... ("all that breathes ...").

The prayer: Nishmat kol hai ("The breath of all").

This literary link may continue toward the beginning of the next section of the service, in Shaharit itself. There, the prayer El Adon contains wording that adds another echo to the end of Psalm 150 and the beginning of Nishmat Kol Hai:

Psalm 15o: Kol ha-neshamah ... ("all that breathes ...").

ElAdon: Kol neshamah ("everyone that breathes").

These three examples of nearly identical wording may constitute an aural thread connecting Pesukei DeZimra with Shaharit.

An important key to the literary structure of the prayer is that the writer of Nishmat Kol Hai was very fond of lists; there are several individual lists, or litanies, of praises within it. The lists are not merely individual thought-units within a longer piece, but rather connect to form an extended and complete thought. That thought is: Even though the gratitude to God that our puny bodies are capable of expressing is wholly inadequate, all we have is our bodies; and therefore it falls to us to utilize all the parts and powers of our bodies to do our inadequate best in expressing our thankfulness. This message culminates with two midrashic interpretations of Scripture; and some individual units within the prayer contain their own midrashic citations of, or expansions on, biblical verses. Indeed, the entire prayer may, in a sense, be viewed as one long midrash.

The first midrashic interpretation is of "All of my bones shall say who is like You" (Ps 35:10), taking this phrase to mean that our limbs themselves ought to be the vehicles of praise to God, and we should not only utilize verbal praise. The second is extracted from Psalm 103:1, "(Let) my soul bless the Lord and (let) all my innards (bless) his holy name." "Soul" and "innards" taken together add up to one's entire physical body. The idea of using one's physical body in praise of God is rare in Jewish liturgy where oral expression is the default mode, and so this prayer stands out in its call for whole body worship. 
The art of this prayer is expressed in the ways that the individual lists are woven together creating the larger call for worship through the physicality of the human body. The following is a chart of the essence of Nishmat that tracks how the lists combine to form the larger message. The bolded words serve as key phrases in the narrative arc of the poem:

The breath of all blesses Your name ...

Beside You, we have no

King

Redeemer

Savior

Liberator

Rescuer

Sustainer

And merciful one

At every time of trouble and distress.

Aside from You, we have no king ... (Note how this last phrase parallels the phrase at the beginning of this list).

YHWH "does not sleep nor slumber" (Ps 121:4)

He wakes the sleeping

Arouses the slumbering

Gives speech to the dumb

Supports the fallen

Raises the bowed low

IF ONLY:

\begin{tabular}{lll}
\hline Parts of the body & Description & Simile \\
\hline Our mouths (were) & $\begin{array}{l}\text { Full of song } \\
\text { (Full of) exultation }\end{array}$ & $\begin{array}{l}\text { As the sea } \\
\text { Our tongues }\end{array}$ \\
Our lips & (Full of) praise & As the breadth of the sky \\
Our eyes & Shining & As the sun and moon \\
Our hands & Outstretched & As the eagles of the heavens \\
Our feet & Swift & As deer
\end{tabular}


WE WOULD STILL NOT MANAGE TO THANK YOU (BECAUSE):

\begin{tabular}{ll} 
Our situation & God's salvation of us \\
\hline From Egypt & You redeemed us \\
From the House of Bondage & You saved us \\
In famine & You fed us \\
In plenty & You sustained us \\
From the sword & You rescued us \\
From plague & You sheltered us \\
From severe enduring sickness & You released us
\end{tabular}

THEREFORE ...

Parts of our body Which you put in us

Limbs Which You placed within us

Spirit and Breath Which You blew into our nostrils

Tongue Which You put into our mouths

THEY THEMSELVES (SHALL) ...

Thank

Bless

Praise

Extol

Exalt

Glorify

Sanctify

Crown 
BECAUSE EVERY ...

\begin{tabular}{ll} 
Body part & Will extol God in these ways \\
\hline Mouth (shall) & Acknowledge You \\
Tongue (shall) & Swear allegiance to You \\
Knee & Shall bend to You \\
Back & Shall bow to You \\
Heart (shall) & Stand in awe of You \\
Innards and Entrails & Shall sing to Your name
\end{tabular}

AS IT IS WRitTEN, “ALl MY BONES SHALl SAY WHO IS LIKE YOU ..." (PS 35:10). ${ }^{13}$

Who compares to You?

Who is equal to You?

Who matches You?

"God great, mighty and awesome" (Deut 10:17).

"Supernal God, creator of heaven and earth" (Gen 14:19).

We shall sing to You

We shall praise You

We shall extol You

We shall bless Your holy name

AS IT SAYS, "OF DAVID: LET MY SOUL BLESS GOD, LET ALL MY INNARDS (BLESS) YOUR HOLY NAME” (PS 103:1).

(Now expanding on each word of Deut 10:17, quoted above):

GOD in the power of Your strength

GREAT through the glory of Your name

MIGHTY forever

AWESOME in Your awesomeness.

13 Elsewhere, this verse is also cited as a possible text for the congregation's response in an 
Thus, the separate components of the poem-many of which comprise lists and encompass biblical verses accompanied by midrashic interpolations — add up to a greater whole: An artfully put together appeal for the worshiper to utilize the entire body in expressing praise and gratitude to God.

\section{Spiritual Commentary}

If any prayer called out for expression in movement it would be Nishmat Kol Hai. To merely recite the words of the prayer seems to miss its very point: All parts of our body must be marshalled to express the gratitude that is due to God for sustaining us in every way. That is both the least we can do-and the most we can do. And the prayer makes the case that we ought to do the most we can do to convey our thanks for God's steadfastness in good times and in bad. The recitation of this prayer calls for swaying in one's seat. It also calls for dance. It calls for creative souls to compose melodies for parts of the poem, or all of it, so that it may be sung and danced to at joyous occasions, and not just at Shaharit of Shabbat and holidays. ${ }^{14}$ It also lends itself to guided meditation of bringing various parts of the body into service of the divine.

Given the religious polemic involved in attributing the prayer to Simon/ Peter, recital of this prayer also calls for some thought about the division and conflict that religion has wrought, along with all of the beauty that religion brings. In opposition to the Jewish-Christian clash embedded in the prayer's history, the opening words of the prayer strike a note of universality:

The breath of all that lives shall bless Your name, and the spirit of all flesh shall glorify and exalt You forever.

The substantial fruits rewarding close reading of this prayer leads one to lament the fact that this richness is usually missed not only by the many worshipers

undertone to the precentor's chant of Modim, "we acknowledge" in the midst of the Ami$d a h$ and this, too, is a moment of physicality, namely bowing. See y. Ber. 1:8, 3d.

14 As we have seen, this prayer migrated from one place in the liturgy - the Haggadah shel Pesah - to another - the conclusion of Pesukei DeZimra on Shabbat and Festivals. Both of these became permanent locations for it. I encourage us to consider other places that the prayer as a whole, or in part, may contribute to the spirit of an occasion on a temporary or one-time basis. It conjures, for me, the Dixie Chicks' 1999 song, "Some Days You Gotta Dance" (Troy Johnson and Marshall Morgan). 
who tend to arrive at the service after Nishmat Kol Hai is recited, but also by those who - following the example of their prayer leaders - are likely to speeddavven through it.

\section{Bibliography}

Eisenstein, J.D. A Digest of Jewish Laws and Customs [in Hebrew]. New York: Hebrew Publishing Company, 1938.

Elbogen, Ismar. Jewish Liturgy: A Comprehensive History. Philadelphia:Jewish Publication Society; New York: Jewish Theological Seminary, 1993.

Goldschmidt, Aryeh, ed. Mą̣zor Vitry, by R. Simhah bar Shmuel. Jerusalem: Mekhon Otsar Ha-Poskim, 2004.

Jellinek, Adolph. Bet ha-Midrasch: Sammlung kleiner Midraschim und vermischter Abhandlungen aus der alteren judischen Literatur. Vienna, 1873 and 1878; Jerusalem, 1938.

Van Bekkum, Wout. "The Poetical Qualities of the Apostle Peter in Jewish Folktale." Zutot 4 (2004): 16-25.

Van Bekkum, Wout. "The Rock on Which the Church Is Founded: Simon Peter in Jewish Folktale." In Saints and Role Models in Judaism and Christianity. Edited by Marcel Poorthuis and Joshua Schwartz, 289-310. Leiden: Brill, 2004. 